\title{
Kernos
}

Revue internationale et pluridisciplinaire de religion grecque antique

7| 1994

Varia

\section{Theology and Theophany in Homer and Minoan Crete}

\author{
Bernard C. Dietrich
}

\section{(2) OpenEdition \\ Journals}

\section{Electronic version}

URL: http://journals.openedition.org/kernos/1096

DOI: 10.4000/kernos. 1096

ISSN: 2034-7871

\section{Publisher}

Centre international d'étude de la religion grecque antique

\section{Printed version}

Date of publication: 1 January 1994

ISSN: 0776-3824

\section{Electronic reference}

Bernard C. Dietrich, «Theology and Theophany in Homer and Minoan Crete », Kernos [Online], 7| 1994, Online since 20 April 2011, connection on 30 April 2019. URL : http://journals.openedition.org/ kernos/1096 ; DOI : 10.4000/kernos.1096 
Kernos, 7 (1994), p. 59-74.

\section{THEOLOGY AND THEOPHANY \\ IN HOMER AND MINOAN CRETE}

Certain phrases on the tablets have an epic dactylic ring to them ${ }^{1}$. Arguably they were remnants of Mycenaean epic ${ }^{2}$. After the destruction of the Bronze Age palaces, Aeolic poets of Boeotia and Thessaly preserved the memory of such epic traditions which travelled to the Ionic colonies in the east before their return and diffusion throughout the Greek world ${ }^{3}$. A recent study traces back Homeric language, characters and themes to Mycenaean via Aeolic and Ionic epic ${ }^{4}$. It is an historically possible route, although the linguistic arguments are not without difficulty 5 .

Like Homeric Greek, Linear B was an artificial language that may never have been spoken. Yet it certainly remained in use over a long period - some 200 years in the case of the latter - and therefore did not follow the usual laws of historical development, spread or dialectal changes ${ }^{6}$. Some 5000 documents in Linear B remain extant with 87 syllabograms. All of them served exclusively administrative purposes and would have provided a poor medium for poetic composition ${ }^{7}$. A few idiosyncratic features of Homeric Greek, which are rare or absent from Linear B and classical Greek, may have descended from Minoan

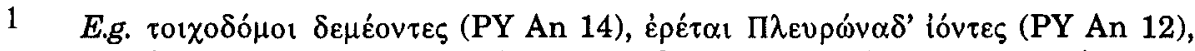

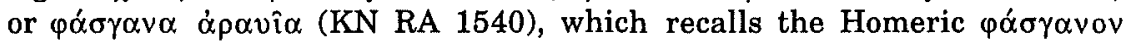
$\dot{\alpha} \rho \gamma v \rho o ́ \eta \lambda o v$.

2 T.B.L. WEBSTER, Homer and the Mycenaean Tablets, in Antiquity, 29 (1955), p. 10-14; From Mycenae to Homer, London, 1958, p. 200-207. The view is criticised by G.S. KIRK, The Songs of Homer, Cambridge, 1962, p. 105-125; 263-265. On the origins of epic diction see now $R$. JANKo in The Iliad: $A$ Commentary, IV : books 13-16, Cambridge, 1992, p. 8-19.

3 C.J. RuIJGH, Le Mycénien et Homère, in A. MoRPurgo-Davies, Y. DuhouX (eds.), Linear B: a 1984 Survey, Cabay-Louvain-la-Neuve, 1985, p. 143-190.

4 M.L. WEST, The Rise of the Greek Epic, in JHS, 108 (1988), p. 151-172.

5 W.F. WYATT Jr., Homer's linguistic forebears, in JHS, 112 (1992), p. 167-173.

6 J. Driessen, Homère et les tablettes en Linéaire $B$, in $A C, 61$ (1992), p. 12; 35.

7 Y. Duнoux, Mycénien et écriture grecque, in Linear B, op. cit. (n. 3), p. 36-37. 
times $^{8}$, but on the whole the case for direct linguistic transmission from Minoan and Mycenaean epic is not strong'.

If such epic existed, as seems likely now, it should be looked for in the oral poetic tradition. This over the centuries absorbed foreign influences, notably from the East, but nevertheless accurately remembered the Aegean past. For example, a good many names of Homeric heroes can be read on the tablets. As it is extremely unlikely that the epic poet borrowed his characters from these palace inventories or the scribes invented them, both drew from an older Minoan and Mycenaean source which was already familiar with the figures and their myths ${ }^{10}$. Other features that hark back to the Bronze Age include Homeric perceptions of time, nature, narrative themes all of which offer interesting technical points of comparison between oral and graphic composition.

Much work has been done recently in comparing epic formulaic techniques with Minoan pictorial forms in wall painting and glyptic art ${ }^{11}$. Repetitive phrases and epithets in oral poetry recall fixed compositional types of Minoan iconography in wall painting and especially on Middle and Late Bronze Age rings with a limited range of designs, figural attitudes and iconographical symbols ${ }^{12}$. Both Aegean artist and

8 E.g. the use of tmesis, G.C. Horrocks, The Antiquity of the Greek Epic Tradition: Some New Evidence, in PCPhS, 206 (1980), p. 1-11.

9 C. Baurain, J. Labarbe, P. Xella, in C. Baurain, C. Bonnet, V. Krings (eds.), Phoinikeia Grammata. Lire et écrire en Méditerranée, Namur-Liège, 1991, p. 69-89; 389-424; 499-532.

10 E. Vermeule, Mythology in Mycenaean Art, in CJ, 54 (1958), p. 97-108; Baby Aigisthos and the Bronze Age, in PCPhS, 33 (1987), p. 122-152; D RIESSEN, art. cit. (n. 6), p. 36 .

11 T. BlavataKaJA, De l'épopée crétoise du XVIIe au XVe s. avant notre ère, in ZAnt, 25 (1975), p. 355-361; HoRROCKs, art. cit. (n. 8), p. 1-11; G. WALBERG, Tradition and Innovation: Essays in Minoan Art, 1986; C. BAURAIN, Recherches sur l'iconographie créto-mycénienne du lion iliadique, in Stemmata. Mélanges J. Labarbe, Liège-Louvain-la-Neuve, 1987, p. 337-367; J. CROWLEY, Subject Matter in Aegean Art: The Crucial Changes, in Aegaeum, 3 (1989), p. 211; S.P. MoRRIS, A Tale of Two Cities: The Miniature Frescoes from Thera and The Origins of Greek Poetry, in AJA, 93 (1989), p. 511-535; S. HILLER, The Miniature Frieze in the West House. Evidence for Minoan Poetry?, in D.A. HARDY, C.G. Doumas, J.A. SAKELlarakis, P.M. WARREN (eds.), Thera and the Aegean World (TAW), III, 1, London, 1990, p. 229-234; C.G. THомAs, Aegean Bronze Age Iconography: Poetic Art?, in Aegaeum, 8 (1992), p. 213220; D RIESSEN, art. cit. (n. 6), p. 32. 
epic poet worked with common themes: teichoscopy, lion hunts, combinations of fighting and pastoral settings, landscapes and the like. Placed side by side, such formulaic elements created continuous narrative scenes, as in the miniature frescoes from the West House on Thera ${ }^{13}$.

With the new palaces Minoans effectively introduced representational painting. In contrast with Egyptian convention artists showed nature as she appears to the eye ${ }^{14}$. Narrative scenes in wall painting and glyptic art could extend over several days of a religious festival, as on the panels of the Hagia Triada sarcophagus ${ }^{15}$. Occasionally one design embraced generic aspects of life, such as the recurring cycle of death and regeneration ${ }^{16}$. Others again compressed a series of events into one frame like the Toreador Frescoes which show all stages of bullleaping in the same picture. Similarly single scenes may suggest both divine arrival and departure ${ }^{17}$; or a god's approach from afar could be frozen in perspective, whether or not he is seen by the human worshippers. Familiar examples of this type are on the gold ring from Isopata and on two sealings from Knossos and Zakros ${ }^{18}$.

Many cultic scenes incorporate a symbolic sign or icon which indicates the type of ritual portrayed. Given the close affinity of Minoan religion to fundamental aspects of nature cult, most will involve the celebration of fertility and rebirth. And the most efficacious of these rituals was the act of blood sacrifice which had as its primary aim the

13 C.A. Televantou, New Light on the West House Wall-Painting, in TAW, op. cit. (n. 11), p. 323; HILLER, art. cit. (n. 11), p. 232-233; Reservations expressed by N. MARINATOS, in TAW, op. cit. (n. 11), p. 235, but modified on p. 325.

14 S.A. Immerwahr, Aegean Painting in the Bronze Age, Pennsylvania Univ. Press, 1990, p. 22.

15 W. PÖTSCHER, Aspekte und Probleme der minoischen Religion, Hildesheim, 1990, p. 171-191.

16 N. Marinatos, Minoan Religion: Ritual, Image and Symbol, Univ. South Carol., 1993, p. 31-36, with full references to the many modern interpretations of the decorations beginning with M.P. NILsson, Minoan-Mycenaean Religion, Lund, $1950^{2}$, p. 426-443.

17 Pötscher, op. cit. (n. 15), p. 134 sq.

18 In F. MATZ, Göttererscheinung und Kultbild im minoischen Kreta, Wiesbaden, 1958, fig. 3; 4; 7. 
release of the powers of renewal through the victim's death ${ }^{19}$. Sacrificial victims occur not infrequently on seals and sealings ${ }^{20}$, but more commonly the occasion is signalled by an appropiate symbol like the double axe as the instrument of sacrifice. In the same category belongs the distinctive sign of the impaled triangle which may be the dagger used in sacrifice, unless it stands for a more obvious sign of female fertility ${ }^{21}$. Both icons may be shown between the horns of a bull's head $^{22}$. On a ring from Vapheio with a ritual scene the axe appears in an elaborate design resembling the Egyptian symbol of life, the ankh $\operatorname{sign}^{23}$. The double axe's symbolic meaning of renewal emerges from its frequent association with butterflies, green shoots of plants and tree. It was a powerful message that carried over into historical Greek tradition $^{24}$.

Such symbols occur regularly on Minoan and Mycenaean rings on their own or in combination with other signs. They signal the general nature of the cultic scene rather than a specific festival, location or even necessarily a particular god. In function they resemble Homeric epithets of individuals and formulaic phrases describing attributes of cities or geographical locations. Homeric usage presents a mix of specific and purely ornamental or generic epithets ${ }^{25}$ some of which may have changed from their first occurrence in Mycenaean ${ }^{26}$. Further-

19 Modern opinion is divided on the meaning of blood sacrifice. For a discussion see B.C. DIETRICH, A Minoan Symbol of Renewal, in JPR, 2 (1988), p.12-24; The Instrument of Sacrifice, in R. HÄGG, N. MARINATOS, G.C. NORDQUIST, Early Greek Cult Practice. Proceedings of the Fifth Intern. Symposium at the Swedish Institute at Athens, Stokholm, 1988 (ActAth, Series in $4^{\circ}, 38$ ), p. 35-40. CMS, II,.3, p. 338 .

21 Iconographic symbols of sacrifice are discussed by N. MARINATOS, Minoan Sacrifice Ritual, Stockholm, 1986, Part II; L.R. PALMER, The Impaled Triangle in Aegean Iconography, 1985.

22 Marinatos, Sacrifice, op. cit. (n. 21), fig. 52; 53.

23 CMS, I, 219.

24 See note 19 above.

25 D. PAGE, History and the Homeric Iliad, Berkeley, 1963, ch. IV; G.S. KIRK, The Iliad I, Cambridge, 1985, p. 173-177; P. VIVANTE, The Epithet in Homer: a Study in Poetic Values, New Haven, 1982; J. PInsent, in L. Foxhald, J.K. Davies (eds.), The Troyan War: its Historicity and Context, Bristol, 1984, p. 141-162; B. HAINSWORTH, The Iliad III, Cambridge, 1993, p. 21-23; 95 etc.

26 HAINSWORTH, op. cit. (n. 25), p. 28-31. 
more, specific epithets can of course be inappropiate to a particular occasion in which a hero becomes involved. Swift-footed Achilles may be sitting in his tent playing the lyre while receiving guests ${ }^{27}$. If the comparison is sound, icons may have operated within an equally wide range of usage, so that they can only loosely be used as guides to particular scenes.

Other curious parallelisms between Homer and Minoan Crete may offer more precise insights. One is the almost total silence regarding temples in both worlds. Certainly neither poet nor Minoan/Mycenaean art provides convincing evidence of separate temples in the city as distinct from the palace along the oriental model. At present only a few exceptions to the rule are known in Crete or the Cycladic islands ${ }^{28}$. Neither is the concept of the temple as the vaós or home of a deity documented before the Pylian $\chi \alpha \lambda$ kiv $\alpha \circ \zeta$ in Linear $\mathrm{B}^{29}$. Minoan and Mycenaean sanctuaries tended to operate in larger connected complexes usually in association with an open space. This is the characteristic layout of the palace sanctuaries, or of the Cult Centre at Mycenae and the structures on the lower acropolis of Tiryns on the mainland ${ }^{30}$. In contrast with the contemporary picture in archaic Greece and the growing number of new foundations from the 8th century B.C., temples in Homer are also few and far between apart from two each for Apollo and Athena as city deities ${ }^{31}$. Equally rare in Homer is the word vaó (Ion. vๆós). perhaps because his gods lived together on Olympus and not in the houses of the city ${ }^{32}$.

$27 I l ., \mathrm{IX}, 196$.

28 E.g. Ayia Irini on Keos. B.C. DIETRICH, Tradition in Greek Religion, Berlin, 1986 , ch. $1 \& 2$.

29 PY Jn 829; L.R. PALMER, The Interpretation of Mycenaean Greek Texts, Oxford, 1963, p. 284; Mycenaeans and Minoans, London, $1965^{2}$, p. 110; M. Ventris, J. ChadWICK, Documents in Mycenaean Greek, Cambridge, $1973^{2}$, p. 513; Dietrich, op. cit. (n. 28), p. 54 sq. \& n. 80 with further references.

30 E. French, Cult Places at Mycenae, in R. HÄGG, N. MARINATos (eds.), Sanctuaries and Cults in the Aegean Bronze Age. Proceedings of the Ist Intern. Symposium at the Swedish Institute at Athens, Stockholm, 1981 (ActAth., Series in- $4^{\circ}, 28$ ), p. 41-48; K. KILIAN, Zeugnisse mykenischer Kultausübung in Tiryns, in Sanctuaries and Cults, op. cit. (n. 30), p. 48-58.

31 Il., I, 39; V, 446; VII, 83 (Apollo); II, 549; VI, 88; 297 (Athena).

32 E. Vermeule, Archaeologia Homerica, III, 5 : Götterkult, Göttingen, 1974, p. 106. 
A most interesting coincidence between Homer and the Minoan world is the absence of cult statues. Votive gifts, including the sacrificial victim, are $\alpha \gamma \alpha \dot{\alpha} \lambda \mu \alpha \tau \alpha$ intended to delight the gods and not represent or incorporate them ${ }^{33}$. A signal exception appears to be a passage in Book 6 of the Iliad. There Athena's priestess Theano offered a $\pi \varepsilon \pi^{\prime} \lambda \circ \varsigma_{\text {to }}$ the goddess in her temple on the acropolis of Troy with the prayer that she might break Diomede's spear and take pity on the Trojan wives ${ }^{34}$. The goddess nodded her refusal to the request. The idea of a moving statue seemed ridiculous and redundant to Aristarchus who promptly athetised the line ${ }^{35}$. But the question is whether the statue was thought to come to life pygmalion-like or momentarily became transformed into the goddess herself ${ }^{36}$, or again whether the verb

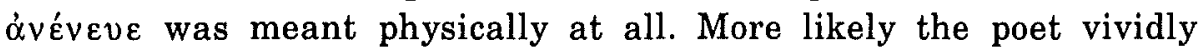
described her refusal which, as so often in Homer, did not require an actual physical divine presence.

As a general rule Homer's gods preferred to communicate indirectly from $\operatorname{afar}^{37}$. Their presence more often than not went unnoticed ${ }^{38}$. They attended their sacrifice unseen ${ }^{39}$. Exceptions to the rule occur as a 'utopian feature' of the fairy tale. The Phaeacians and far distant Ethiopians were on familiar terms with the gods ${ }^{40}$, unlike ordinary

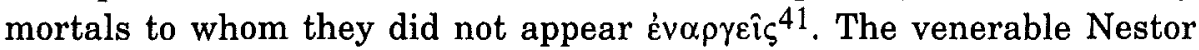
might be excused for boasting that he saw Athena at the feast which he had prepared for Poseidon ${ }^{42}$. But her actual appearance ( $(\alpha \vee v \varepsilon \hat{\sigma} \sigma \alpha)$ in the shape of a large, beautiful woman to Odysseus alone and to his dogs is unusual, indeed quite unlike her encounter with Achilles in $\mathrm{Il}$.

33 Od., III, 274; 438; VIII, 509; XII, 347; cf. DIETRICH, op. cit. (n. 28), p. 102.

34 Il., VI, 305-311.

35 Schol. A ad loc.

36 MATZ, op. cit. (n. 18), p. 437; VERMEULE, op. cit. (n. 32), p. 121.

37 B.C. DiETRICH, Divine Epiphanies in Homer, in Numen, 30 (1983), p. 62 for examples.

38 Od., XIII, 299-302; 318.

39 Od., III, 435.

40 Od., VII, 201 with H.B. HaInsworth's note ad loc. in A Commentary on Homer's Odyssey I,Oxford, 1988; Il., I, 423.

$41 O d ., \mathrm{XVI}, 161$.

42 Od., III, 420. 
$1,194 \mathrm{f} .43$. Yet such confrontations are imagined as possible in Homer and cause little surprise to the human actors when they do happen. This epic idea of feasible but unlikely divine epiphany continued in Greek literature and beyond. Its tenacious hold over popular imagination may be judged from the ludicrous incident at Lystra, which is told in the New Testament. The people there mistook St.Paul and his companion Barnabas for epiphanies of Olympian Zeus and Hermes ${ }^{44}$.

Homeric values prescribed the standard for Greek vase painters in the black-figure style of the 6th century and in the following red-figure technique from the end of that century. The gods clearly preferred their own company 45 . Precisely the same kind of remote, primarily invisible, engagement in human affairs obtained in archaic and classical Greek temple sculpture. Gods acted out their myths among themselves on their own level. When shown together with men, they intervene or rather control human affairs unseen.

Both Apollo and Zeus on the pediments of Zeus' temple at Olympia illustrate Homeric concepts of divine functioning. The commanding central figure of Apollo with right arm outstretched in the west pediment frontally addresses the outside observer but remains invisible to the fighting Lapiths and Centaurs in the scene. The sculpture lies between archaic and classical, but the content is expressed in Homeric terms except of course that the poet's audience hears rather than sees what is going on. Divine $\pi \alpha \rho o v \sigma i \alpha$ is ubiquitous in the poems and intervention continuous, but it normally occurs in the form of mental rather than direct visual interaction. That explains the 'remarkable paradox that nearly every important event in the Iliad is the doing of a god, and that one can give a clear account of the poem's entire action with no reference to the gods at all ${ }^{46}$.

Athena's intervention in Iliad I differs from her refusal to accede to Theano's prayer in Book 6. She appears only to Achilles: her eyes flash, and she grasps the hero by his hair ${ }^{47}$. Her mission is to prevent him from killing the superior king in a fit of anger. The physical details of

43 Od., XVI, 126. Cf. A. HoEKsTRA's comment ad loc. in Homer's Odyssey II, Oxford, 1989.

44 Acts XIV, 11-12.

45 J. BOARDMAN, Athenian Black Figure Vases, London, 1975, p. 224.

46 JANKo, op. cit. (n. 2), p. 4.

47 Il., I, 197-200. 
the scene notwithstanding, the incident seems less of an epiphany than the poet's manner of expressing the outcome of Achilles' own mental processes. The passage perfectly illustrates Bruno Snell's thesis that Homeric epic externalised or objectified human decisions ${ }^{48}$. The

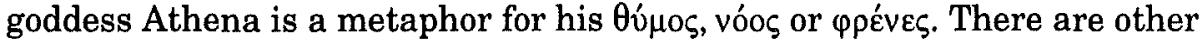
occasions, however, on which divine intervention is explicitly physical, as when, for instance, Apollo bodily removes Aeneas out of Diomede's reach and places him in the Trojan citadel, or when Paris is rescued from the battlefield by Aphrodite who carries him off to Helen's bedchamber 49 .

The gods are strong, beautiful, fast like thought ${ }^{50}$, and they cast about them the radiance of light 51 . But they are measured by human standards, albeit on an exaggerated scale ${ }^{52}$. Ajax surmises a divine presence by the size of the shins and footprints that he can see ${ }^{53}$. These different views of divine functioning combine to confuse the poet's vision of epiphany. The gods' anthropomorphism conflicts with the perception of their supernatural powers. Athena is pictured as a swallow up in the rafters of Odysseus' hall ${ }^{54}$, yet some 50 lines on she brandishes her dread aegis (297). Apollo's image at the beginning of the Iliad varies between the anthropomorphic god and a malignant divine power. At one moment he is striding down Mt.Olympus with his quiver and arrows ringing on his shoulders, and the next he is an evil plague descending like night on the Achaean army. Thetis, too, changes from swirling sea mist into a human figure when she appears before her son Achilles later in the same Book 55 . What then are we to make of the talking

48 B. SNELL, Die Entdeckung des Geistes, Göttingen, $1948^{2}$. See the discussion with bibliography in B.C. DIETRICH, Views of Homeric Gods and Religion, in Numen, 26 (1979), p. 142 sq. \& n. 76-78. Snell's view continues to be very influential in Homer studies, e.g. H. ERBSE, Untersuchungen zur Funktion der Götter im homerischen Epos, Berlin, 1986; T. JAHN, Zum Wortfeld 'Seele . Geist' in der Sprache Homers, München, 1987.

49 Il., III, 380-382.

$50 \quad I l ., \mathrm{XV}, 80-83$.

51 Od., XIX, 37-40; 43.

52 Cf. W. BURKERT, Greek Religion, transl. J. Raffan, Oxford, 1985, p. 182-189.

53 Il., XIII, 71 sq.

54 Od., XXII, 240.

55 Il., I, 44-49; 359-362; DiETRICH, art. cit. (n. 37), p. 53 sq. 
Scamander, both deep-eddying river $(\beta \alpha \theta v \delta i$ vi $\varsigma)$ and speaking to Achilles in a human voice ${ }^{56}$ ?

Such episodes have fostered an extreme view of Homer's gods as creations of epic convention and outside religion ${ }^{57}$. That judgment fails to take into account the long history and nature of epic religion compounded of divine myth and faith - and its enormous contribution to polis cult 58 . The functioning of Homer's gods followed traditions from the pre-archaic past creating a chronologically unreal element in Homeric theology. In Homer the gods interact directly with his heroes; divine and human motivation overlap or coincide 59 . The two can be difficult to separate in an illusory epic world hovering between real and seeming. Apollo sends a false image, an $\varepsilon i \delta \omega \lambda o v$, which looks like Aeneas, weapons and all, for the Achaeans to fight over ${ }^{60}$. Once he substitutes himself for the Trojan Agenor whom he saves from Achilles' fury $^{61}$. He resembles the hero (źoıḱ́s) and therefore seems the same as Aeneas' $\varepsilon i \delta \omega \lambda_{0 v}$ in Book 562. Metaphor and simile merge in this and in other divine interventions. Socrates disapproved of Homeric thinking and commented critically on divine metamorphosis into human and animal shape in Homer and the poets. Perfect beings, he said, could only change into something less; and he therefore blamed these gods for changing their forms, or at least making us believe that they do 63 .

Matz argued that in the Theano episode of Iliad 6 the statue becomes the goddess ${ }^{64}$. That cannot be right; but he touches on the essence of Homeric fluidity between mentally comprehended (or narrated) and actually seen intervention, that is between divine action and epiphany.

$56 I l ., \mathrm{XXI}, 212-221$.

57 M.P. NILSSON, Geschichte der griechischen Religion, I, München, 1967³, p. $219 ; 368$ sq.; H. LLOYD-JONES, The Justice of Zeus , Berkeley, 19832 , p. 9 sq.

58 DiETRICH, op. cit. (n. 28), p. 180-182.

59 A. LESKY, Göttliche und menschliche Motivation im homerischen Epos, Heidelberg, 1961 (SHAW, 1961, 4); JANKO, op. cit. (n. 2), p. 4, with further references.

$60 \quad I l, \mathrm{~V}, 449 \mathrm{sq}$.

61 B.C. FeniK, Typical Battle Scenes in the Iliad, Wiesbaden, 1968, p. 12; 48; cf. N. RICHARDSON, The Iliad VI, Cambridge, 1993, p. 103 sq.

62 ǐèov. Cf. KIRK, op. cit. (n. 25), p. 107 sq.

63 Rep. II, 381b-d.

64 MATZ, op. cit. (n. 18), p. 437. 
It is difficult to judge how important the distinction would appear to Homer's contemporaries who may have felt less perturbed by the vague boundaries between man, animal, plants and even lifeless objects. The proximity of all parts of nature emerges from the use of Homeric similes in which heroes all but become the plants or animals to which they are compared 65 . Two parallel scenes on the legs of a Geometric tripod cauldron from Olympia reproduce this kind of affinity pictorially. A human duel mirrors a pair of fighting lions in attitude and form 66 .

Homer operates in a linguistic and religious limbo. Regular cults and festivals are suppressed. Only the instruments of cult match contemporary archaic practice like the rituals of prayer and sacrifice. The latter drew from the oriental custom of viewing the sacrificial victim as food for the gods. They flock like flies to the savour of burnt meat ${ }^{67}$. However, suspended within this 'Sammelbecken' of foreign accretions epic preserved Minoan/Mycenaean traditions regarding form and manner of divine functioning, as well as the astonishingly close relationship of man with nature. Minoan iconography suggests a similar direct communication of man with his gods. As in Homer, man's experience of the divine is portrayed both in scenes of cultic ritual and of myth 68 .

Minoan deities are notoriously difficult to identify from the extant pictures. There are as yet few if any reliable criteria beyond the size of figures, their compositional prominence or frontal position, gesture and attribute. Opinion is divided whether gods are shown in anthropomorphic, theriomorphic, or in aniconic shape. Familiar theophoric names on the Linear $B$ tablets cannot easily be matched to pictorial

65 E.g. P. Vivante, Homer, Yale Univ. Press, 1985 (Hermes Books); M.W. EDWARDS, The Iliad V, Cambridge, 1991, p. 24-41, for a discussion of this large topic with up-to-date bibliography.

66 8th century B.C., Olympia Archaeol. Mus. B 1730; A. MAllwitz, H.V. Herrmann, Die Funde aus Olympia, Athens, 1980, p.44, no. 16.

67 ANET $^{3}$ (1969), p. 95 (Gilgamesh); cf. the Egyptian ritual, ibid., p. 325; sacrifices to the gods of Uruk, ibid., p. 342-345, etc.; Éd. DHORME, Les religions de Babylonie et d'Assyrie, Paris, 1949, p. 221; 222; KIRK, op. cit. (n. 25), p. 1213.

68 Still a contentious subject, W. BURKERT, Structure and History in Greek Mythology and Ritual, Berkeley, 1979 (Sather Classical Lectures, 47), p. 187, n. 25 with references. 
representations ${ }^{69}$. These problems await resolution. They may in fact turn out to be of our own making, if divine power manifested itself in all three and indeed in hybrid forms ${ }^{70}$. The apparent ambiguity recalls epic views of epiphany which in turn reflect Homeric affinity to all aspects of nature. This applies particularly to the easy relationship, not to say interchangeability, between human and animal form. Homeric bird epiphanies may be a special case; but they do illustrate the difficulty in distinguishing between belief, myth or poetic device. Are they gods, or do they merely have divine qualities ${ }^{71}$ ? Similar doubt attaches to Minoan scenes of divinities accompanied by birds ${ }^{72}$. Are they intended as messengers, signs of divine presence, or are they gods themselves ${ }^{73}$ ? Most probably the artist cared as little for a precise definition as the poet in epic epiphanies like that of Athena in Odyssey $22^{74}$.

By their nature aniconic epiphanies are virtually impossible to detect in painting and glyptic art. Minoan religion is rich in symbolism, the most prominent of which the double axe may signal the sacredness of a place or occasion. Large and miniature votive axes are found in most sanctuaries, or the sign was engraved on pillar tomb or sanctuary wall. It practically dominates ritual scenes on rings, and it watches over funerary cult as on the Hagia Triada sarcophagus. The

69 S. HILler, Mykenische Archäologie, in SMEA (1979), p. 193; DIETRICH, op. cit. (n. 28), p. 117.

70 A full review of the modern bibliography on the topic can be found in R. HÄGG, Die göttliche Epiphanie im minoischen Ritual, in $M D A I(A), 101$ (1986), p. 41-62. Further recent discussions include W.D. NIEMEIER, $Z$ ur Deutung des Thronraumes im Palast von Knossos, in MDAI(A), 101 (1986), p. 63-95; Das Stuckrelief des 'Prinzen mit der Federkrone' aus Knossos und minoische Göttervorstellungen, in AM, 102 (1987), p. 65-98; Fragen und Probleme der bronzezeitlichen ägäischen Glyptik, in CMS (1989), p. 163-186; PÖTSCHER, op. cit. (n. 15); MARINATOS, op. cit. (n. 16), ch. 7 \& 8.

71 DIETRICH, art. cit. (n. 37), p. 57-59.

72 NIEMEIER, art. cit. (n. 70), 1987, p. 86; art. cit. (n. 70), 1989, p. 174.

73 NILSSON, MMR, op. cit. (n. 16), p. 330-340; GGR, op. cit. (n. 57), p. 290-292; MATZ, op. cit. (n. 18), p. 402-403, sees the bird as a divine presence. The 'Vogelepiphanie' could be a god or sign; A. FURUMARK, Gods of Ancient Crete, in OAth, 6 (1965), p. 92 : the bird is a 'divine determinative'; NIEMEIER (n. 70); MARINATOS, op. cit. (n. 16), p. 133; 156; PÖTSCHER, op. cit. (n. 15), p. 106-107: bird, like snake, was a 'theriomorphe Erscheinungsform der Göttin'.

74 Above n. 54. 
double axe is clearly emblematic of divine power ${ }^{75}$, it may even mark a divine presence ${ }^{76}$, but it is neither a goddess or god ${ }^{77}$. Other objects that are frequently associated with ritual scenes like tree, pillar, baetyl or stalagmite in some form incorporated divine power ${ }^{78}$. None, however, received cult in their own right ${ }^{79}$. Trees and pillars were unlikely media of divine epiphanies in Minoan belief ${ }^{80}$, but signposts or markers of a divine presence in human form ${ }^{81}$.

Such scenes are depicted on neopalatial gold rings of the Late Bronze Age. The relatively few with anthropomorphic figures have been examined in detail and classified in separate types of ritual scenes involving divine and human interaction ${ }^{82}$. Gods are invoked by gesture, offering, libation or sacrifice ${ }^{83}$. On a gold ring from Knossos a god staff in hand appears to a worshipper from above. His progress through the air is indicated by his hair flying in the wind and by his downward pointed toes ${ }^{84}$. On a reconstructed seal impression also from Knossos with the so-called Mother of the Mountains, the goddess has already arrived. She stands on a mountain peak holding out a staff with the same imperious gesture before a worshipper in the attitude of adoration. Goddess and mountain are heraldically flanked by two lions

75 NiLsSON, MMR, op. cit. (n. 16), ch. 6, p. 194-235.

76 B. RUTKowsKI, Frühgriechische Kultdarstellungen, Berlin, 1981, p. 96.

77 As argued by PÖTSCHER, op. cit. (n. 15), p. 144.

78 E.g. PM I, 221; B.C. DiETRICH, The Origins of Greek Religion, Berlin, 1973, p. 84-87, etc.

79 For the popular belief in the existence of Minoan tree and pillar cult see the pioneering study by A. EVANs, The Mycenaean Tree and Pillar Cult, in JHS,21 (1901), p. 99-204; cf. $P M$ I, p. 161; NILSSON, $M M R$, op. cit. (n. 16), ch. VIII, p. 262-288 (tree-cult); ch. VII, p. 236-261, on pillar and columns as structural elements only; B. RuTKowski, The Cult Places of the Aegean, Yale Univ. Press, 1986, p. 143-144, argues in favour of pillar cult.

80 For a contrary view see PöTSCHER, op. cit. (n. 15), p. 97, who includes columns in his category of divine epiphany in object form - 'dingliche'.

81 'Kultmale', MATZ, op. cit. (n. 18), p. 420-423; NIEMEIER, art. cit. (n. 70), 1986, p. 85-86; 1989, p. 172; MARINATOS, op. cit. (n. 16), p. 179-181.

82 HÄGG, art. cit. (n. 70), p. 56-58; NIEMEIER, art. cit. (n. 70), 1989, p. 163-186.

83 NiEMEIER, art. cit. (n. 70), 1989, p. 167-169, fig. 1; MATZ, op. cit. (n. 18), p. 388390; 407; HÄGG, art. cit. (n. 70), p. 56; 58.

84 Niemeier, art. cit. (n. 70), 1989, p. 169, fig. 2, 1; MARINATOS, op. cit. (n. 16), p. 172-173, fig. 171. 
in a characteristically Minoan and Mycenaean composition ${ }^{85}$. Another type of set scene shows two figures of the same size at least one of which is divine ${ }^{86}$.

Quite unambiguous examples of divine confrontation are depicted in representations of a goddess who is seated on a platform or throne, next to a sanctuary, tree or column ${ }^{87}$. The scenario is imaginary. The goddess is accompanied by the fabulous griffin 88 , while receiving worship from men as well as animals like goat and monkey 89 . Occasionally both humans and animals pay their respects together in the same ritual ${ }^{90}$. A splendid fresco from Xeste 3 at Akrotiri on Thera shows the goddess sitting on a tripartite platform attended by a griffin and accepting gifts of saffron from a girl and from a monkey ${ }^{91}$. On a famous gold ring from Tiryns the goddess welcomes a processional group of mythical daemonic creatures carrying rhyta presumably with libations in her honour ${ }^{92}$.

The settings are mythological: the artist draws a ritual performance in which the goddess is imagined or known to be there but not seen. A much discussed ring from Isopata shows the arrival of a deity in the presence of a group of priestesses or worshippers who are engaged in a ritual dance. The performance may have been calculated to invite the god who nevertheless remained unseen ${ }^{93}$. Here and elsewhere in comparable scenes, the arrival of a deity is invoked by dance, music and sacrifice ${ }^{94}$, but as a rule he/she remains invisible to the worship-

85 A. EVAns, The Palace of Minos, III, London, 1930, p. 463; NILSSON, MMR, op. cit. (n. 16), p. 352-353; N IEMEIER, art. cit. (n. 70), 1989, p. 169, fig. 2, 4.

86 HÄGG, art. cit. (n. 70), p. 56; NIEMEIER, art. cit. (n. 70), 1989, p. 171-172, fig. 3 , 1-12.

87 NiEMEIER, art. cit. (n. 70), 1989, p. 173, fig. 4, 1-15.

88 E.g. seal from Rhodes CMS V, 2, no. 654; cf. CMS I, 128.

89 MARINATOS, op. cit. (n. 16), p. 160, fig. 144.

90 Monkey beside human figure, CMS II, 3, no. 103.

91 Restored: N. MARINATOS, Art and Religion in Thera, Athens, 1984, fig. 40; 44; EAD., op. cit. (n. 16), fig. 122; 213.

$92 \quad P M$ IV, p. 460-462, fig. 385; NILSSON, $M M R$, op. cit. (n. 16), p. 147, fig. 55; NIEMEIER, art. cit. (n. 70), 1989, p. 173, fig. 4, 13.

93 CMS II, 3, no. 51. Discussed with references by NIEMEIER, art. cit. (n. 70), 1989, p. 165; cf. MARINATOS, op. cit. (n. 16), p. 176-177.

94 HÄGG, art. cit. (n. 70), p. 61. 
pers. On the Isopata ring the epiphany has a distinctly epic flavour: it is viewed from within. The observer does not look on from outside as a bystander but becomes part of the scene in true Homeric fashion. Matz aptly compares the technique with Homer's description of a hunt on Odysseus' golden brooch which converts a work of plastic art into the real world of narrative and simile ${ }^{95}$.

In Minoan religion direct confrontation is possible between man or his priestly representative and god. It happens near a sacred tree or shrine and in the open as a rule ${ }^{96}$. As in Homer, encounters of this kind seem relatively uncommon, however, and similarly confined to the realm of myth. Some quite elaborate compositions show a goddess arriving at her shrine by boat ${ }^{97}$, riding on a griffin 98 , or side-saddle like Europa on the back of a bull. Her arms are upraised in the characteristic 'Segnungsgestus' of deities ${ }^{99}$. All these scenes are obviously drawn from myth.

Divine $\pi \alpha \rho o v \sigma i \alpha$ was as universal and natural in the Minoan/ Mycenaean world as in that of Homeric epic and evidently defined by similar basic parameters. Like epic poets, and indeed archaic Greek vase painters and sculptors, Minoan artists showed gods visiting their festivals. The ambience of both call to mind Thales' enthusiastic belief in a world that is filled with gods. Communication with divinity occurred through no iconic or aniconic divine image within a temple or particular sanctuary. It was direct albeit unseen as a rule. The word epiphany is something of a misnomer therefore in Minoan religion as much as in Homer for describing divine intervention in human affairs. More often than not epiphany happened as an individual experience: the encounter was intensely personal, psychological almost, as in the case of Athena and Achilles in Iliad I. Divine presence was in

95 Od., XIX, 226-231, 'Dingliche Bildvorstellung', op. cit. (n. 18), p. 437.

96 NIEMEIER's Group III (art. cit. [n. 70], 1989, p. 170-172: either man/deity, or priest as deity, or between two deities.

97 E.g. ring from Mochlos: goddess arrives at her shrine in a boat, CMS II, 3, no. 252; NILSSON, MMR, op. cit. (n. 16), p. 269-270; MARINATOS, op. cit. (n. 16), p. 163 , fig. 150 .

98 On a seal from Mycenae, CMS I, no. 167.

99 Glass plaque from Dendra/Midea, NiLsson, GGR, op. cit. (n. 57), pl. 26, 7. On similar scenes with discussion of mythological scenes see $M M R$, op. cit. (n. 16), p. 34-40; D IETRICH, op. cit. (n. 78), p. 310-314. 
the mind, so to speak, it was visionary rather than visual. Only the artist actually visualised it in his composition ${ }^{100}$.

There is no doubt that Minoan and Mycenaean deities were conceived of as imminent powers. A group of surviving divine names are obviously invocatory: Europa, 'The Far Seeing', Pasiphae, 'The Allseeing', Ariadne, 'The Holy One', or Aphaia, 'The Unseen'101. The important divine titles Mistress, Lady, Queen, Potnia, Wanassa etc., share this quality. They are known from Linear $B$ and retain something of their function in Homer ${ }^{102}$. Some architectural remains also suggest a strong revelatory element in cultic performance. The Throne Room at Knossos involved an expected, imagined or perhaps even staged divine presence ${ }^{103}$. Parallel rituals about an empty throne survived in historical times. The best known is that of Zeus which was periodically placed in the Idaean Cave in expectation of his coming 104 . The so-called Balustrade Shrine in the Royal Villa at Knossos or the House of the Chancel Screen seem almost purpose-built for revealing a vision of the divine, or at least an enacted event of this nature. Its plan of two or more rising levels with strategically placed barriers and entrance through a $\pi 0 \lambda v \operatorname{\theta } \theta \rho o v$ certainly points to the same kind of ritualised divine revelation 105 .

Pictorially invocations are shown as lively occasions involving enthusiastic dance, excited gestures and movement. The impression is un-Homeric and has an ecstatic Dionysiac quality about it 106 . Evidently divine presence is deliberately invoked rather than spontaneous. The scene more closely compares with the cletic Homeric Hymn, that is with a particular ritual moment and not with epic narrative. In both the impact of divine arrival is artistically imagined, however. In the great Hymn to Apollo the manner of the god's visit to his

100 Cf. Marinatos, op. cit. (n. 16), p. 243.

101 DiETRICH, op. cit. (n. 78), p. 180, 305.

102 B. Hemberg, Anax, Anassa und Anakes, Uppsala, 1955; Dietrich, op. cit. (n. 78), p. 180-184.

103 HÄGG, art. cit. (n. 70), p. 47; NIEMEIER, art. cit. (n. 70), 1986, p. 63-95, with references to modern discussions.

104 D IETRICH, op. cit. (n. 28), p. 99.

105 HÄGG, art. cit. (n. 70), p. 47-55.

106 MATz, op. cit. (n. 18), p. 447. 
temple in Delphi is no less ambiguously described than other visualised epiphanies in Homer ${ }^{107}$.

Still, mysteries remain. It seems unreasonable to expect that Minoan gods functioned any more uniformly than Homer's Götterapparat. The common bond between the two lies in a basically similar perception of divine operation. That similarity is no chance coincidence but arose from an extended historic tradition. There are indications that the Minoans possessed a more or less complex divine mythology which artists skilfully integrated in their portrayals of cultic scenes like their Greek descendants. A Minoan goddess occurs more frequently and prominently than a god. Yet both existed, nor was the latter an obviously second-class citizen in the divine hierarchy or imprisoned in the rôle of an évıoviò $\delta \alpha i \mu \omega v^{108}$. Their relationship with men was close not to say immediate in a kind of intensified Homeric atmosphere. The Minoan gods were present in all parts of nature. They did not need to become manifest within an image or in living anthropomorphic shape.

B.C. DieTrich

University of Wales GB - ABERYSTWYTH

107 D IETRICH, art. cit. (n. 37), p. 70-71.

108 Cf. N IEMEIER, art. cit. (n. 70), 1989, p. 183. 